\title{
RACJONALNOŚĆ I SKUTECZNOŚĆ PLANOWANIA NA PRZYKŁADZIE GMINNEGO PROGRAMU PROFILAKTYKI I ROZWIĄZYWANIA PROBLEMÓW ALKOHOLOWYCH
}

\section{WPROWADZENIE}

Orzecznictwo sądów oraz wypowiedzi doktryny dotyczące aktów planowania i ich miejsca w systemie źródeł prawa jest bogate. Nie poświęcono jednak szerszej uwagi ani w orzecznictwie, ani w literaturze kwestii skuteczności tych aktów. W opracowaniu odnosimy się do fragmentu tego zagadnienia na przykładzie gminnego programu profilaktyki i rozwiązywania problemów alkoholowych. Celem artykułu jest wzbogacenie argumentacji dotyczącej oceny skuteczności tego aktu i zasadności jego sporządzania.

\section{ZASADY PROPORCJONALNOŚCI I RACJONALNOŚCI TWORZENIA I WYKONYWANIA PRAWA}

Wyposażenie organów władzy publicznej w kompetencję do stanowienia prawa i nakładania na jednostkę praw i obowiązków może być okazją do wielu nadużyć prawodawczych. W literaturze przedmiotu ${ }^{1}$ zasadnie wskazuje się więc, że prawodawca powinien podejmować środki adekwatne do zamierzonych celów, a zasada proporcjonalności wyznacza granice władzy prawodawczej i stanowi pewne zabezpieczenie przed nadmierną ingerencją ustawodaw$\mathrm{cy}^{2}$. Zasada proporcjonalności nakazuje organom użycie środków niezbędnych do osiagnięcia konkretnego celu. Władza ma osiagać cel jak najmniejszym kosztem, a środki zastosowane do jego realizacji muszą być proporcjonalne, niezbędne i najwłaściwsze. Istotą zasady proporcjonalności jest więc miarkowanie działań organów administracji publicznej oraz konieczność dostosowania tych działań do założonych celów. Między celem regulacji a środkami

\footnotetext{
${ }^{1}$ Por. J. Zakolska, Zasada proporcjonalności w orzecznictwie Trybunału Konstytucyjnego, Warszawa 2008, s. 5.

2 Zob. Ł. Folak, Zasada proporcjonalności w tworzeniu prawa administracyjnego, „Ruch Prawniczy, Ekonomiczny i Socjologiczny” 79, 2017, z. 4, s. 57.
} 
postępowania powinny zachowane być odpowiednie proporcje i uzasadniona adekwatność ${ }^{3}$.

Zasada proporcjonalności obejmuje nie tylko proces stosowania prawa, lecz także etap jego tworzenia ${ }^{4}$. Jest ona pewnym instrumentem kontroli wykorzystywanym przez sądownictwo konstytucyjne i administracyjne, które wskazuja, że zasada ta jest jedna z kardynalnych zasad prawidłowej legislacji wywodzonej z konstytucyjnej zasady demokratycznego państwa prawa. Koncepcja racjonalnego prawodawcy znajduje swoje odzwierciedlenie również w praktyce stosowania prawa, czego dowodzi orzecznictwo sądów administracyjnych i Trybunału Konstytucyjnego ${ }^{5}$. Naczelny Sąd Administracyjny ${ }^{6}$ wyraził pogląd, że każde działanie władzy w demokratycznym państwie prawnym podporządkowane musi być zasadzie proporcjonalności, odnoszącej się do ogółu sytuacji, w których państwo za pomoca stanowionego przez siebie prawa wpływa na podmioty pozostajace pod jego władza. Według Trybunału Konstytucyjnego ingerencja ustawodawcy jest dopuszczalna, gdy zakłada adekwatność środka i celu. Ustawodawca powinien tak kształtować prawo, aby stanowiło skuteczny środek do osiagania założonego celu ${ }^{7}$. Wybór środków służących realizacji obranego przez prawodawcę celu powinien być dokonany zgodnie z założeniami racjonalnego tworzenia prawa. Ustawodawca powinien ocenić skutki uboczne, jakie przyniesie ze sobą zamierzona regulacja i porównać z wartością celu, do którego zmierza. Stwierdzenie, że efekty uboczne przekraczają wartość zamierzonego celu, powinno prowadzić do uznania takiej regulacji za niezgodna z racjonalnym modelem tworzenia prawa ${ }^{8}$. Zasada proporcjonalności stanowi zawężenie zakresu swobody prawodawcy; nawet jeśli użyty środek jest przydatny i konieczny do osiagnięcia założonego celu, nie można go zastosować, jeżeli nie jest to usprawiedliwione wagą oraz charakterem tego celu ${ }^{9}$. Prawodawca może ustanawiać nowe przepisy jedynie wtedy, gdy uzyskają pozytywny wynik testu zasady proporcjonalności, która przewiduje wprowadzenie do systemu prawa określonego unormowania wówczas, gdy:

1) jest niezbędne dla ochrony interesu publicznego;

2) kształtuje regulacje w sposób umożliwiający osiagnięcie założonych celów;

3) zachowane są proporcje między efektem regulacji a ciężarem i niedogodnościami nałożonymi na jednostkę ${ }^{10}$.

${ }^{3}$ K. Wojtyczek, Zasada proporcjonalności, w: B. Banaszak, A. Preisner (red.), Prawa i wolności obywatelskie w Konstytucji RP, Warszawa 2002, s. 669.

${ }^{4}$ Z. Duniewska, Zasada proporcjonalności, w: M. Stahl (red.), Prawo administracyjne. Pojęcia, instytucje, zasady w teorii i orzecznictwie, Warszawa 2013, s. 147.

${ }^{5}$ M. Zirk-Sadowski, Instytucjonalny i kulturowy wymiar integracji prawnej, w: L. Leszczyński (red.), Zmiany społeczne a zmiany w prawie, Lublin 1999, s. 41.

${ }^{6}$ Wyrok NSA z 14 lutego 2012 r., II OSK 2249/10, CBOSA.

${ }^{7}$ Wyrok TK z 18 października 2011 r., SK 2/10, Dz. U. Nr 240, poz. 1439; wyrok TK z 12 kwietnia 2000 r., K 8/98, Dz. U. Nr 28, poz. 352.

${ }^{8}$ Orzeczenie TK z 20 listopada 1996 r., K 27/95, OTK 1996, nr 6, poz. 50.

9 A. Walaszek-Pyzioł, Zasada proporcjonalności w orzecznictwie Trybunału Konstytucyjnego, „Przegląd Ustawodawstwa Gospodarczego” 1995, nr 1, s. 16.

${ }^{10}$ Z. Kmieciak, Ogólne zasady prawa i postepowania administracyjnego, Warszawa 2000, s. 19. 
Zasady proporcjonalności i racjonalnego tworzenia prawa wynikają z Konstytucji oraz rozporządzenia Prezesa Rady Ministrów z 20 czerwca 2002 r. w sprawie „Zasad techniki prawodawczej”"11. Trybunał wielokrotnie odwoływał się do zawartych tam dyrektyw, podkreślając istotne znaczenie dla poprawnego formułowania prawa. Przestrzeganie z.t.p., zdaniem TK, stanowi poszanowanie zasad pewności, bezpieczeństwa prawnego oraz ochrony zaufania do państwa i prawa. Przekroczenie pewnego poziomu niejasności przepisów stanowić może przesłankę stwierdzenia ich niezgodności z art. 2 Konstytucji, z którego wynika nakaz określoności prawa ${ }^{12}$. Stosownie do $§ 1$ ust. 1 z.t.p. podjęcie decyzji o przygotowaniu projektu aktu prawnego poprzedza się m.in. ustaleniem możliwości podjęcia środków interwencji organów władzy alternatywnych do uchwalenia ustawy. W przypadku podjęcia decyzji o przygotowaniu projektu należy określić cele, jakie zamierza się osiagnąć przez uchwalenie nowego prawa, ustalić rozwiązania alternatywne, które mogą służyć osiagnięciu założonych celów, oraz dokonać wyboru optymalnego w danych warunkach rozwiązania. Ustanowienie nowego prawa jest tylko jednym z potencjalnych środków oddziaływania umożliwiających osiagnięcie założonych celów. Z przepisu $§ 1$ ust. 2 pkt 7 z.t.p. wynika dyrektywa racjonalności technicznej ustawodawcy, zakładająca, że spośród alternatywnych rozwiązań prawnych należy wybrać te, które w danych warunkach sa optymalne i najbardziej sprzyjające osiagnnięciu założonych celów, tj. takie, które:

1) najskuteczniej prowadzą do realizacji założonych celów;

2) wymagają poniesienia najmniej kosztownych nakładów;

3) wiążą się z najmniejszą ilością niepożądanych skutków ubocznych.

Zasady proporcjonalnego i racjonalnego tworzenia prawa uzupełnia zasada minimalizacji interwencji prawodawczej, oznaczająca, że na inicjatywę ustawodawczą należy się zdecydować wówczas, gdy udowodniono, że stan prawny po interwencji będzie znacząco lepszy od stanu przed interwencją prawodawcza, a użycie innych środków niż prawne byłoby mniej skuteczne. Adam Pogdórecki, który zajmował się zasadą minimalizacji prawodawczej, twierdził, że „lepsza jest norma dotychczasowa niezupełnie poprawna niż norma prawdopodobnie niewadliwa"13. Jerzy Bafia podkreślał, że niebezpieczna jest wiara w omnipotencję prawa i tworzenie prawa fikcyjnego. Zasada realności prawa wskazywać ma na obiektywne zapotrzebowanie na daną regulację prawną ${ }^{14}$.

Sławomira Wronkowska wskazuje, że spośród możliwych i legalnych sposobów oddziaływania należy wybrać środki skuteczne dla osiagnięcia celów założonych, a zarazem możliwie najmniej uciążliwe dla podmiotów, wobec których będą stosowane, lub dolegliwe w stopniu nie większym, niż jest to niezbędne do osiagnięcia założonego celu ${ }^{15}$. Należy zatem ustalić katalog wszyst-

${ }^{11}$ Dz. U. 2016, poz. 283 (dalej jako: z.t.p.).

${ }^{12}$ Wyrok TK z 29 października 2003 r., K 53/02, OTK-A 2003, nr 8, poz. 83.

${ }^{13}$ A. Podgórecki, Założenia polityki prawa. Metodologia pracy legislacyjnej i kodyfikacyjnej, Warszawa 1957, s. 88.

${ }_{14}$ J. Bafia, Zasady tworzenia prawa, Warszawa 1984, s. 111.

${ }^{15} \mathrm{~S}$. Wronkowska, Zarys koncepcji państwa prawnego $w$ polskiej literaturze politycznej i prawnej, w: eadam (red.), Polskie dyskusje o państwie prawa, Warszawa 1995, s. 74. 
kich możliwych środków, które mogłyby służyć osiagnięciu pożądanych zmian, przy czym należy wziąć pod uwagę inne środki oddziaływania (perswazyjne, organizacyjne, zmianę interpretacji przepisów), a nie zakładać, że należy ingerować przez prawo, gdyż nie zawsze jest to właściwy, a zwykle kosztowny sposób osiagania celu ${ }^{16}$.

Znaczenie zasady racjonalnego tworzenia prawa podkreślali również uczestnicy Forum Debaty Publicznej zorganizowanego przez Prezydenta RP, którzy wskazywali, że proces stanowienia prawa powinien zmierzać do rozwiąania problemu regulacyjnego przez jak najmniejszą ingerencję $\mathrm{w}$ system prawny. Zmiany prawa powinny następować wyłącznie wtedy, gdy nie ma możliwości innego rozwiązania problemu niż ingerencja prawodawcy. Analiza innych opcji rozwiązania danej kwestii (np. samoregulacja) powinna uwzględniać uciążliwość proponowanej ingerencji w porównaniu z celem, który prawodawca zamierza osiagnąc ${ }^{17}$.

Proces przygotowania prawa polegać powinien na wyłonieniu takiego rozwiązania prawnego, które umożliwia zrealizowanie zamierzonego celu w sposób optymalny, które najpełniej realizuje zamierzone cele przy możliwie najmniejszym obciążeniu budżetu państwa i społeczeństwa. Ustalenie, że uchwalenie aktu normatywnego jest $\mathrm{w}$ danym przypadku niezbędne, daje podstawy do podjęcia decyzji o przygotowaniu projektu takiego aktu ${ }^{18}$.

\section{AKTY PLANOWANIA - ZAGADNIENIA OGÓLNE}

Wskazane wyżej zasady dotyczą nie tylko stanowienia prawa powszechnie obowiązującego, lecz również, zgodnie z $§ 141$ i 143 z.t.p., odpowiednio trybu podejmowania aktów prawa wewnętrznego oraz prawa miejscowego, które sa źródłami prawa powszechnie obowiązującego na obszarze działania organów ustanawiających dany akt. Przepisy z.t.p., określajace, jak właściwie kształtować treść przepisów, wskazują np. na konieczność przestrzegania ogólnych zasad tworzenia aktów normatywnych - proporcjonalność, komunikatywność, skrótowość czy zakaz powtarzania przepisów innych źródeł prawa.

Nie wszystkie akty prawne wydane przez organy samorządu terytorialnego sa aktami prawa miejscowego w rozumieniu Konstytucji. Konstytucyjne regulacje dotyczące źródeł prawa powoduja, że organy administracji publicznej moga wydawać akty normatywne tylko w ramach określonych w art. 87 i art. 93 Konstytucji. Takie ukształtowanie prawnych form działania traktowane jest $\mathrm{w}$ naukach administracyjnoprawnych jako istotne ograniczenie

16 S. Wronkowska, M. Zieliński, Zasady techniki prawodawczej. Komentarz, Warszawa 2004, s. 23.

17 System stanowienia prawa w Polsce. Zielona Księga, Kancelaria Prezydenta RP, Warszawa 2013, s. 92, <www.prezydent.pl> [dostęp: 24.02.2018].

${ }_{18}$ G. Wierczyński, Redagowanie i ogłaszanie aktów normatywnych. Komentarz, Warszawa 2016, s. 51. 
możliwości wykonywania prawa przez administrację ${ }^{19}$. W literaturze ${ }^{20}$ wska- $^{-}$ zuje się na dyskusję przedstawicieli nauki prawa konstytucyjnego oraz administracyjnego w kwestii katalogu źródeł prawa oraz rozumienia pojęcia aktu normatywnego ${ }^{21}$. Przedstawiciele nauki prawa administracyjnego problematykę źródeł prawa administracyjnego wiążą nie tylko z aktami normatywnymi jako źródłami prawa administracyjnego, lecz także z tzw. niezorganizowanymi źródłami prawa administracyjnego, stanowiącymi szczególne źródła tej gałęzi prawa ${ }^{22}$.

Eugeniusz Ochendowski podkreślał, że w systemie prawa występuje wiele swoistych źródeł prawa, których istota jest trudna do ustalenia, dotyczy to m.in. aktów planowania, programów, zawierających normy o zróżnicowanym charakterze - ogólne, indywidualne, informacyjne ${ }^{23}$. Lech Morawski uważał, że granica między tworzeniem a stosowaniem prawa nie jest wyraźna, a w wielu aktach normatywnych zaliczanych do aktów tworzenia prawa znajdują się normy indywidualne lub konkretne ${ }^{24}$. Podobnie konstatował Jan Zimmermann, który twierdził, że ustawodawca przestał mieścić się w klasycznych podziałach i często stanowi takie formy działania administracji, które łamia dotychczasowe kryteria klasyfikacji ${ }^{25}$.

Przemiany w sposobach działania administracji sa rezultatem $\mathrm{m}$.in. zwiększania liczby zadań administracji publicznej, zmian organizacyjnych, cywilizacyjnych itp. Wzrost znaczenia tych swoistych form działania administracji nastapił po akcesji Polski do Unii Europejskiej. Aktywność planistyczna służyć miała stymulowaniu i koordynacji działań oraz aktywizacji działań różnych podmiotów. Formy te różnią się charakterem prawnym, stopniem mocy wiążącej, mogą mieć znaczenie wyłącznie informacyjne, indykatywne lub wiążące ${ }^{26}$. Akty planowania przybierają różną postać; moga mieć formę aktów normatywnych powszechnie obowiązujących (ustawa budżetowa, plan zagospodarowania przestrzennego) bądź aktów polityki i aktów generalnych ${ }^{27}$.

${ }^{19}$ W. Federczyk, B. Majchrzak, Akt normatywny w orzecznictwie Trybunatu Konstytucyjnego. Problemy na tle aktów organów administracji, w: M. Błachucki, T. Górzyńska (red.), Źródła prawa administracyjnego a ochrona wolności i praw obywateli, Warszawa 2014, s. 168.

${ }^{20}$ Zob. K. Ziemski, Indywidualny akt administracyjny jako forma prawna działania administracji, Poznań 2005.

${ }^{21}$ L. Garlicki, Konstytucyjne źródła prawa administracyjnego, w: R. Hauser, Z. Niewiadomski, A. Wróbel (red.), System prawa administracyjnego, t. 2: Konstytucyjne podstawy funkcjonowania administracji publicznej, Warszawa 2012, s. 48.

${ }^{22}$ P. Dobosz, Quasi-akty prawa miejscowego, w: S. Dolata, Problemy prawne w działalności samorzadu terytorialnego, Opole 2002, s. 128.

23 E. Ochendowski, Prawo administracyjne, część ogólna, Toruń 2002, s. 127.

${ }^{24}$ L. Morawski, Wstęp do prawoznawstwa, Toruń 1997, s. 79.

25 J. Zimmermann, Prawo administracyjne, Warszawa 2008, s. 283.

${ }^{26}$ E. Olejniczak-Szałowska, Tworzenie planów, programów, strategii, w: M. Stahl (red.), Prawo administracyjne. Pojęcia, instytucje, zasady w teorii i orzecznictwie, Warszawa 2016, s. 512.

${ }_{27}$ M. Stahl, Akty planowania (akty polityki), w: R. Hauser, Z. Niewiadomski, A. Wróbel (red.), System prawa administracyjnego, t. 5: Prawne formy działania administracji, Warszawa 2013 , s. 366. 
Występowanie nienormatywnych aktów administracji znalazło potwierdzenie w orzecznictwie. Trybunał Konstytucyjny ${ }^{28}$, oceniając przepisy dotyczące zarządzania kryzysowego, uznał, że uchwały Rady Ministrów o przyjęciu raportu o zagrożeniach bezpieczeństwa narodowego oraz Narodowym Programie Ochrony Infrastruktury Krytycznej nie mają charakteru aktów prawa wewnętrznego. Trybunał wskazał, że poza zakresem źródeł prawa wewnętrznego pozostaja akty organów administracji pozbawione cech normatywności - należą do nich plany, strategie, programy i analizy ${ }^{29}$. Naczelny Sąd Administracyjny przyją ${ }^{30}$ natomiast, że plan zagospodarowania częstotliwości nie jest aktem normatywnym powszechnie obowiąujacym ani aktem prawa wewnętrznego. Plan taki można zaliczyć do grupy „swoistych źródeł prawa administracyjnego", a jego skutki wykraczaja poza ramy organizacyjne administracji rządowej.

Treść planów wyznacza przepis prawa powszechnie obowiązującego, który w pewnych przypadkach określa szczegółowo przedmiot planowania, w innych określa jedynie pewne konieczne elementy bądź pozostawia całość regulacji do dowolnego uznania, wskazując jedynie np. tytuł planu. Te nieprecyzyjne regulacje wpływają na treść, jakość i skuteczność aktów planowania. Należy zgodzić się z tym, że cele powinny być określone w sposób wymierny, a nie ogólnikowy (np. zamiast zwiększenia bezpieczeństwa na drogach publicznych należy zaplanować zmniejszenie liczby wypadków o określony procent w określonym czasie) $)^{31}$.

Norma wynikająca z planu programuje postępowanie adresatów, nakazując im dążenie do celu za pomocą określonych środków, zgodnie z formułą cel $\rightarrow$ środki $^{32}$. Normy takie określają zadania do wykonania, sposób ich realizacji zaś powinien być określony ogólnie, aby pomioty zobowiązane do wykonania miały swobodę w wyborze środków służących wykonaniu planu. Normy te uchwalane są na czas określony, po którym tracą moc. W przypadku wykonania planu dochodzi do „skonsumowania” zawartych w nim norm. Adresatami aktów planowania są jednostki odpowiedzialne za jego wykonanie. Normy planu moga mieć zatem charakter wewnętrzny i indywidualno-konkretny; plany, co do zasady, nie mają waloru aktów prawa miejscowego, choć wyjątkowo np. plan zagospodarowania przestrzennego jest aktem prawa miejscowego ${ }^{33}$.

Przy tworzeniu planów należy zwrócić uwagę na konieczność unikania określania sztywnych granic i metod aktywności; należy mieć na uwadze fakt,

${ }^{28}$ Wyrok TK z 3 lipca 2012 r., K 22/09, OTK-A 2012, nr 7, poz. 74.

${ }^{29}$ W. Federczyk, B. Majchrzak, Akt normatywny w orzecznictwie Trybunału Konstytucyjnego. Problemy na tle aktów organów administracji, w: M. Błachucki, T. Górzyńska (red.), Źródta prawa administracyjnego a ochrona wolności i praw obywateli, Warszawa 2014, s. 169.

${ }^{30}$ Wyrok NSA z 25 maja 2006 r., II GSK 43/06, CBOSA.

${ }^{31}$ K. Wlaźlak, Racjonalność planowania $w$ prawie administracyjnym, Warszawa 2015, s. 165 .

${ }^{32}$ M. Szydło, Planowanie indykatywne jako funkcja państwa wobec gospodarki, w: B. Popowska (red.), Funkcje wspótczesnej gospodarki. Księga dedykowana Profesor Teresie Rabskiej, Poznań 2006, s. 150.

${ }^{33}$ D. Dąbek, Prawo miejscowe samorządu terytorialnego, Bydgoszcz-Kraków 2003, s. 195. 
że istnieje więcej niż jeden scenariusz kształtowania (planowania) przyszłości. Plany mają regulować sytuacje mające powstać w przyszłości, co jest związane z cechą względności norm planowych ${ }^{34}$. Racjonalność planowania wymaga sformułowania odpowiedzi na podstawowe zagadnienia, tj.:

1) cel planu i działania prowadzace do jego osiagnięcia;

2) termin realizacji poszczególnych etapów planu;

3) przestrzeń dotycząca działania;

4) podmioty realizujące działania;

5) koszty działań;

6) źródła finansowania ${ }^{35}$.

Planowanie powinno mieć formę skoordynowanych wielostronnych działań, w tym także nieformalnych, nastawionych na osiagnięcie określonych celów ${ }^{36}$. Wydaje się, że większe znaczenie dla racjonalności planowania powinno mieć ustalenie celu każdego planu.

Jeszcze bardziej radykalnym, ale zasługującym na rozważenie rozwiązaniem, może być rezygnacja z tworzenia wielu sektorowych programów i uchwalenie wyłącznie strategii uwzględniającej różne kwestie problemów społecznych (przemoc w rodzinie, narkomania, alkoholizm). Praktyczna przydatność planowania budzi bowiem poważne wątpliwości, zauważalny jest wzrost regulacji zobowiązujących administrację do podejmowania działań planistycznych, przy czym w wielu przypadkach podmioty odpowiedzialne za formułowanie i realizację planów nie są przygotowane do wykonywania nałożonych zadań, także pod względem finansowym ${ }^{37}$.

\section{GMINNY PROGRAM PROFILAKTYKI I ROZWIĄZYWANIA PROBLEMÓW ALKOHOLOWYCH}

Jednym z planów obligatoryjnie opracowywanych przez gminy jest plan dotyczący problemu nadużywania alkoholu. Prawna regulacja tego zjawiska nie ma ani wyłącznego, ani zasadniczego wpływu na jego skalę; specyfika problemu alkoholizmu zależy od szeregu pozaprawnych czynników. Zadania w zakresie wychowania w trzeźwości i przeciwdziałania alkoholizmowi zostały powierzone m.in. samorządom gminnym, które mają obowiązek opracowania programu profilaktyki i rozwiązywania problemów alkoholowych ${ }^{38}$. Ustawa

${ }^{34}$ H. Rot, K. Siarkiewicz, Zasady tworzenia prawa miejscowego, Warszawa 1994, s. 59.

${ }^{35}$ M. Ziółkowski, Zarzqdzanie strategiczne $w$ polskim samorzadzie terytorialnym, w: A. Zalewski (red.), Nowe zarzaddzanie publiczne w polskim samorzadzie terytorialnym, Warszawa 2007, s. 105.

${ }^{36}$ R. Stankiewicz, Prawotwórcza rola administracji w ksztattowaniu sektora energetycznego (na przyktadzie polityki energetycznej państwa), w: M. Stahl (red.), Legislacja administracyjna. Teoria, orzecznictwo, praktyka, Warszawa 2012, s. 256.

${ }^{37}$ K. Wlaźlak, op. cit., s. 217.

${ }_{38}$ B. Jaworska-Dębska, Prawna regulacja problemów uzależnień, obrotu napojami alkoholowymi, środkami odurzajacymi i psychotropowymi, wyrobami tytoniowymi, w: M. Stahl (red.), Materialne prawo administracyjne. Pojęcia, instytucje, zasady, Warszawa 2002, s. 167. 
z 26 października 1982 r. o wychowaniu w trzeźwości i przeciwdziałaniu alkoholizmowi ${ }^{39}$ przewiduje, że zadania polegające na minimalizowaniu negatywnych skutków spożywania alkoholu i przeciwdziałaniu nadmiernemu spożyciu są elementem polityki państwa, która jest realizowana lub wspierana przez szereg podmiotów, m.in. przez organy samorządu terytorialnego, administracji rządowej, kościoły i związki wyznaniowe itp. Pewne zadania z zakresu profilaktyki alkoholowej wykonują również samorządy województwa, jednakże uprawnienia te sa nieprecyzyjne i nie sa powiązane $\mathrm{z}$ działaniami podejmowanymi na szczeblu centralnym, mimo że organy te powinny harmonijnie koordynować działania samorządu terytorialnego i administracji rządowej na szczeblu centralnym. Ustawodawca zwraca szczególną uwagę na kwestie profilaktyczne, tj. przeciwdziałanie negatywnym (społecznym, zdrowotnym, ekonomicznym) skutkom spożywania alkoholu.

Podstawa realizacji zadań z zakresu przeciwdziałania alkoholizmowi jest gminny program profilaktyki i rozwiązywania problemów alkoholowych (dalej: „program profilaktyki”) ustanawiany corocznie na podstawie art. $4^{1}$ ust. 2 u.w.t., w drodze uchwały rady gminy. Poglądy doktryny oraz orzecznictwo sadowe ${ }^{40}$ jednoznacznie wskazuja, że akt ten nie ma waloru aktu prawa miejscowego, a jako akt wewnętrzny obowiązuje jedynie organy gminy i określa plan ich działania. Postanowienia programu sa bowiem indywidualno-konkretne (ustalają określone działania, które mają być wykonane przez organ), a ich moc wygasa po wykonaniu tych zadań. Choć programy profilaktyki nie maja waloru aktów prawa miejscowego, sa przyjmowane w sformalizowanej i długiej procedurze uchwałodawczej. Zachowanie wymogów proceduralnych jest istotnym warunkiem ważności uchwały - nie można zmienić ustalonego wieloetapowego ciagu czynności (inicjatywa uchwałodawcza, sporządzenie projektu, opiniowanie, uzgodnienie, przedłożenie uchwały, postępowanie na sesji rady, stwierdzenie kworum, głosowanie, podpisanie, publikacja).

Przepis art. $4^{1}$ u.w.t., stanowiący podstawę prawną programów profilaktyki, ma niejednorodny charakter. Określa on zadania własne gminy w zakresie rozwiązywania problemów alkoholowych (ust. 1), upoważnia radę gminy do opracowania programu profilaktyki oraz powołania pełnomocnika do jego realizacji (ust. 2), zawiera upoważnienie dla wójta (burmistrza, prezydenta) do powołania gminnej komisji rozwiązywania problemów alkoholowych ${ }^{41}$ (ust. 3) oraz przewiduje obowiązek odpowiednich szkoleń dla członków komisji i zasady ich wynagradzania (ust. 4 i 5). Taka systematyka przepisu art. $4^{1}$ u.w.t. powoduje trudności interpretacyjne ${ }^{42}$. Ustawą z 10 stycznia 2018 r. o zmianie ustawy o wychowaniu w trzeźwości i przeciwdziałaniu alkoholizmowi oraz ustawy o bezpieczeństwie imprez masowych ${ }^{43}$ wprowadzono obowiązek uwzględniania

${ }^{39}$ Dz. U. 2016, poz. 487 (dalej jako: u.w.t.).

${ }^{40}$ Wyrok NSA z 23 czerwca 2003 r., II SA/Po 502/03 CBOSA.

${ }^{41}$ Zob. D. Lebowa, W. Maciejko, Gminna komisja rozwiazywania problemów alkoholowych, Warszawa 2011.

42 I. Skrzydło-Niżnik, G. Zalas, Ustawa o wychowaniu w trzeźwości i przeciwdziałaniu alkoholizmowi. Komentarz. Doktryna. Orzecznictwo, Warszawa 2002, s. 40.

${ }^{43}$ Dz. U. poz. 310. 
przepisów programu profilaktyki przez uchwały regulujące dostęp do alkoholu (dotyczące takich kwestii, jak: maksymalna liczba zezwoleń na sprzedaż, usytuowanie miejsc sprzedaży, podawania i spożywania, godziny sprzedaży napojów alkoholowych). Przepisy tej ustawy weszły w życie z dniem 9 marca 2018 r., zatem uchwały wydawane od tego dnia na podstawie art. 12 ust. 1-7 u.w.t. będa musiały być skorelowane z przepisami programu profilaktyki.

Program profilaktyki powinien obejmować kwestie wskazane w art. $4^{1}$ ust. 1 u.w.t., tj.:

1) zwiększanie dostępności pomocy terapeutycznej i rehabilitacyjnej dla osób uzależnionych od alkoholu;

2) udzielanie rodzinom, w których występuja problemy alkoholowe, pomocy psychospołecznej i prawnej, a w szczególności ochrony przed przemoca w rodzinie;

3) prowadzenie profilaktycznej działalności informacyjnej i edukacyjnej w zakresie rozwiązywania problemów alkoholowych i przeciwdziałania narkomanii, w szczególności dla dzieci i młodzieży, w tym prowadzenie pozalekcyjnych zajęć sportowych, a także działań na rzecz dożywiania dzieci uczestniczących w pozalekcyjnych programach opiekuńczo-wychowawczych i socjoterapeutycznych;

4) wspomaganie działalności instytucji, stowarzyszeń i osób fizycznych, służącej rozwiązywaniu problemów alkoholowych;

5) podejmowanie interwencji w związku z naruszeniem przepisów określonych w art. $13^{1}$ i 15 u.w.t. oraz występowanie przed sądem w charakterze oskarżyciela publicznego;

6) wspieranie zatrudnienia socjalnego przez organizowanie i finansowanie centrów integracji społecznej.

Wbrew wskazanym wyżej ustawowym wymogom, często w programach profilaktyki znajdują się informacje wykraczające poza zakres przedmiotowy programów, np. dane statystyczne, medyczne, fragmenty europejskich lub krajowych aktów prawnych. W każdym przypadku przekroczenie granic upoważnienia budzi wątpliwości systemowe i legislacyjne. Mając na uwadze cel programu profilaktyki, powinien on analizować skalę zjawiska problemów alkoholowych występujących w gminie oraz punkt odniesienia jego dalszych ustaleń co do zakresu działań podejmowanych w ramach działań własnych gminy. Plany muszą pozostawać w ścisłym związku z lokalną rzeczywistością i powinny uwzględniać kompleksową ocenę lokalnych problemów, pozwalającą na dobór środków zmniejszających skalę zjawiska nadużywania alkoholu ${ }^{44}$.

Doktryna wskazuje, że wzrocowo opracowany program profilaktyki powinien określać:

1) analizę i ocenę problemów alkoholowych występujących w gminie (ewentualnie pojawiające się tendencje);

2) zasadnicze cele ( $\mathrm{z}$ uwzględnieniem celów ustawowych), jakie gmina stawia sobie w tym zakresie;

44 I. Sierpowska, Pomoc społeczna. Komentarz, Warszawa 2014, s. 140. 
3) środki prowadzące do osiagnięcia tych celów;

4) wielkość środków i źródła finansowania planu ${ }^{45}$.

W artykule dokonano analizy programów profilaktyki kilku losowo wybranych gmin. Treść tych dokumentów budzi poważne wątpliwości. Należy zwrócić uwagę na przykład na następujące kwestie:

- uchwała nr XXXIV/207/2017 Rady Gminy Tymbark z 28 grudnia 2017 r. w sprawie: przyjęcia „Gminnego Programu Profilaktyki i Rozwiązywania Problemów Alkoholowych oraz Narmoanii (sic!) na terenie Gminy Tymbark na rok 2018”46 modyfikuje nazwę ustawowego organu, tj. komisji rozwiąywania problemów alkoholowych, na gminną komisję rozwiązywania problemów alkoholowych i narkomanii. Niezgodność ta budzi wątpliwości z punktu widzenia hierarchii źródeł prawa;

- uchwała nr XCI/2389/17 Rady Miasta Krakowa z 20 grudnia 2017 r. w sprawie przyjęcia Gminnego Programu Profilaktyki i Rozwiązywania Problemów Alkoholowych oraz Przeciwdziałania Narkomanii na rok $2018^{47}$ zawiera zbędne szczegółowe dane statystyczne i zestawienia tabelaryczne niezwiąane z jakimikolwiek działaniami podejmowanymi na rzecz trzeźwości, dotyczące np. ilości turystów, którzy odwiedzają Kraków, deklarowanego czasu poświęcanego na sport, konsekwencji spożycia alkoholu przez kobiety ciężarne w poszczególnych trymestrach ciąży;

- uchwała nr L/507/2017 Rady Gminy Szczecinek z 28 grudnia 2017 r. w sprawie przyjęcia Gminnego Programu Profilaktyki i Rozwiązywania Problemów Alkoholowych oraz Przeciwdziałania Narkomanii na 2018 rok $^{48}$ zawiera liczne powtórzenia przepisów rozporządzenia Prezesa Rady Ministrów z 4 sierpnia 2016 r. w sprawie Narodowego Programu Zdrowia na lata 20162020 (Dz. U. poz. 1492). Powielanie przepisów powszechnie obowiązujących w akcie prawa wewnętrznego jest normatywnie zbędne, a ponadto może wywołać błędne wrażenie co do zakresu obowiązywania takich norm;

- uchwała nr 454/XLIII/2017 Rady Miejskiej w Lublińcu z 14 grudnia 2017 r. w sprawie przyjęcia „Gminnego Programu Profilaktyki i Rozwiązywania Problemów Alkoholowych oraz Przeciwdziałania Narkomanii na 2018 rok" ${ }^{49}$ zawiera zbędne informacje sprawozdawcze z lat ubiegłych dotyczace działania komisji rozwiązywania problemów alkoholowych (np. ilość przeprowadzonych rozmów motywujących, ilość wniosków skierowanych do sądu w sprawie obowiązu leczenia itp.). Uchwała ta dotyczy zatem zdarzeń przeszłych, a nie przyszłych, nie zawiera typowych norm planowych;

${ }^{45}$ Z. Duniewska et al., Plany, strategie, programy $i$ inne zbliżone formy prawne dziatania administracji, w: Podmioty administracji publicznej i prawne formy ich działania. Studia i materiały z Konferencji Naukowej Poświęconej Jubileuszowi 80-tych urodzin Profesora Eugeniusza Ochendowskiego, Toruń 2005, s. 164.

${ }^{46}$ Zob. <https://bip.malopolska.pl/ugtymbark,a,1407597,uchwala-nr-xxxiv2072017-rady-gminy-tymbark-z-dnia-28-grudnia-2017-r-w-sprawie-przyjecia-gminnego-pro.html> [dostęp: 4.02.2018].

47 Zob. <https://www.bip.krakow.pl/?dok_id=167\&sub_dok_id=167\&sub=uchwala\&query=id\% 3D23093\%26typ\%3Du> [dostęp: 4.02.2018].

${ }^{48}$ Zob. <http://bip.gminaszczecinek.pl/index.php?id=209284> [dostęp: 4.02.2018].

${ }^{49}$ Zob. <http://www.lubliniec.bip.info.pl/dokument.php?iddok=14294\&idmp=231\&r=r> [dostęp: 4.02.2018]. 
- uchwała nr XLVII/305/2017 Rady Miejskiej w Szprotawie w sprawie Gminnego Programu Profilaktyki i Rozwiązywania Problemów Alkoholowych i Narkomanii w Gminie Szprotawa na 2018 r. ${ }^{50}$ nakłada na gminę liczne obowiązki, które nie wynikają z u.w.t. i do których realizacji gmina nie posiada ani kompetencji, ani środków finansowych (np. „zmniejszanie naruszeń prawa na rynku alkoholowym”, „wzmacnianie kompetencji członków Komisji, pracowników oświaty w zakresie przepisów prawa").

Jak wynika z powyższych przykładów, jakość uchwał stanowiących podstawę do realizowania zadań gmin w sferze wychowania w trzeźwości i przeciwdziałania alkoholizmowi budzi uzasadnione zastrzeżenia. Należy zwrócić uwagę na brak korelacji z innymi ustawami, w tym z ustawą o przeciwdziałaniu narkomanii, które powinny jednolicie regulować problematykę rozwiąywania problemów zapobiegania nałogom. Wydaje się również, że ustawodawca nie ma jasnej koncepcji udziału organów administracji publicznej w rozwiązywaniu tych problemów i przeciwdziałania im. Nieczytelny jest podział zadań pomiędzy administrację centralną i terenowa, co powoduje, że zachodzić może brak koordynacji tych działań. Wydaje się, że sposobem na rozwiązanie tego problemu jest kompleksowa analiza społecznej sfery problemu uzależnień i rozważenie uregulowania zadań administracji publicznej w jednym akcie prawnym, co spowodować może konsolidację działań administracji w walce z tym trudnym i społecznie niebezpiecznym zjawiskiem, jakim jest alkoholizm ${ }^{51}$.

Wątpliwości budzi finansowanie programu profilaktyki polegające na uzależnieniu planu od liczby wydanych zezwoleń na sprzedaż alkoholu ${ }^{52}$, a próbą zwiększenia skuteczności tych programów mogłoby być odnalezienie innych źródeł finansowania, w tym zakresie np. Robert Sawuła proponuje, aby gmina uzyskiwała pewien udział w podatku akcyzowym od sprzedanego alkoholu ${ }^{53}$. Doktryna wśród przesłanek prawnej ingerencji w kwestię profilaktyki wskazuje również skalę, w jakiej występuje problem alkoholizmu, brak możliwości oddziaływania na to zjawisko za pomoca środków innych niż prawne, interdyscyplinarny charakter tych problemów implikujacy oddziaływanie na nie w sposób kompleksowy ${ }^{54}$.

Na niską jakość i efektywność programów profilaktyki zwróciła uwagę Najwyższa Izba Kontroli, która uznała, że programy te nie realizują celu usta$\mathrm{wy}^{55}$. „Informacja o wynikach kontroli pobierania oraz wykorzystania przez

${ }^{50}$ Zob.<http://bip.wrota.lubuskie.pl/ugszprotawa/system/obj/1346_305.pdf> [dostęp: 26.02.2018].

${ }^{51}$ R. Budzisz, B. Jaworska-Dębska, K. Wlaźlak Rola samorzadu terytorialnego w zakresie wychowania w trzeźwości i przeciwdziałania alkoholizmowi, „Studia Prawno-Ekonomiczne” 80, 2009, s. 85.

${ }^{52}$ K. Wlaźlak, op. cit., Warszawa 2015, s. 224.

${ }^{53}$ R. Sawuła, Administracyjnoprawne środki ograniczenia dostępności alkoholu. Uwagi na tle nowelizacji ustawy o wychowaniu w trzeźwości i przeciwdziałaniu alkoholizmowi, „Samorząd Terytorialny" 1997, nr 3, s. 58.

${ }_{54}$ B. Jaworska-Dębska, Spór wokót modelu polskiej regulacji alkoholowej. Zagadnienia administracyjnoorawne, Łódź 1995, s. 184.

${ }_{55}$ A. Krakała, I. Wąsowska, Ograniczenie dostępności napojów alkoholowych jako przyktad legislacji administracyjnej $w$ gminach, w: M. Stahl, Z. Duniewska (red.), Legislacja administracyjna. Teoria, orzecznictwo, praktyka, Warszawa 2012, s. 508. 
samorządy województw i gmin opłat za zezwolenia na sprzedaż napojów alkoholowych w latach 2006-2008"56 wskazuje, że w 37,5\% skontrolowanych jednostek NIK stwierdziła nierzetelność, ogólnikowość, brak rzetelnej analizy lokalnych potrzeb, a nawet przypadki przepisywania innych programów (np. narodowych, wojewódzkich). W ocenie NIK stwarza to zagrożenie nieefektywnego wykorzystania środków, a organom pozostawia zbyt dużą swobodę w ich wydatkowaniu. W innym dokumencie dotyczacym „Realizacji i wykorzystania przez samorządy województw i gmin dochodów z opłat za korzystanie z zezwoleń na sprzedaż napojów alkoholowych ${ }^{57 "}$ NIK stwierdziła m.in., że „w realizacji zadań z zakresu profilaktyki i rozwiązywania problemów alkoholowych najczęściej występująca nieprawidłowością był brak dostatecznie rzetelnej analizy potrzeb lokalnych".

W doktrynie systematycznie pojawiają się postulaty rezygnacji z ustawowego obowiazku opracowania programu profilaktyki i pozostawienia tej kwestii do ustalenia w drodze aktu prawa miejscowego opracowanego stosownie do potrzeb lokalnych ${ }^{58}$. Zwolennicy tego rozwiązania wskazuja, że pozwoliłoby to na bardziej elastyczne dostosowanie organizacji zadań dotyczących kwestii trzeźwości, z uwzględnieniem lokalnej specyfiki, skali problemu itp. Programy, na podstawie których prowadzona jest polityka zwalczania alkoholizmu, nie przynoszą zakładanych efektów. Należy oczekiwać, że zmiany u.w.t. dokonane nowelizacją z 10 stycznia 2018 r. i ściślejsze związanie wszelkich aktów normatywnych dotyczących profilaktyki alkoholowej z warunkami lokalnymi doprowadzą do zmiany dotychczasowego stanu.

\section{PODSUMOWANIE}

Transformacja ustroju społeczno-politycznego i przystapienie do Unii Europejskiej zapoczątkowały dynamiczny rozwój działalności planistycznej. Przedmiotem planowania są zadania z różnych dziedzin życia - zagospodarowanie przestrzenne, ochrona przyrody, gospodarka odpadami i pomoc społeczna. Ocena racjonalności planowania wymaga sformułowania propozycji zmian w kierunku rozważenia potrzeby opracowania niektórych z nich. Uzasadnione wydaje się dokonanie rewizji racjonalności niektórych planów z punktu widzenia całkowitych kosztów związanych z ich opracowaniem i wykonaniem. Poglądy doktryny podają w wątpliwość zasadność opracowania niektórych

56 Znak: LPO-41025-00/08, Poznań 2009, s. 7, <https://www.nik.gov.pl/kontrole/wyniki-kontroli-nik/pobierz,px_remote_lpo_p_08_151_200812021147571228214877_02,typ,kk.pdf> [dostęp: 7.02.2018].

57 27/2013/P/12/165/LPO, <https://bip.nik.gov.pl/.../wyniki-kontroli-nik/pobierz,lpo p_12_165_ 2012120515515> [dostęp: 7.02.2018].

58 R. Budzisz, B. Jaworska-Dębska, K. Wlaźlak, op. cit., s. 63, tak też A. Krakała, I. Wasowska, op. cit., s. 508, oraz K. Wlaźlak, Racjonalność planowania w prawie administracyjnym, Warszawa 2015, s. 217. 
planów ${ }^{59}$, Trybunał Konstytucyjny zaś wyraża przekonanie, że „wszelkie działania prawodawcy są efektem dogłębnego rozważenia problemu i dojrzałej decyzji, znajdujacej racjonalne uzasadnienie"60.

Skuteczność programów profilaktyki mogłyby zwiększyć tzw. działania nieformalne w administracji, do których zalicza się działania o charakterze informacyjnym (np. porady, rekomendacje). Maja one charakter wspierajacy i zapobiegawczy, są działaniami niewyczerpujaco uregulowanymi w prawie, ale też nie są z nim sprzeczne. Są ważnym elementem uzupełniającym i stymulującym wypełnianie zadań przez administrację i w porównaniu z sformalizowanymi działaniami administracji, przy zapewnieniu podobnego stopnia osiaganego celu i skuteczności, są o wiele tańsze, szybsze, bardziej adekwatne do potrzeb społecznych. Należy także podkreślić, że proces stanowienia uchwał jest długi, kosztowny i nie jest w stanie zmierzyć się z dynamicznie rozwijajacca się rzeczywistością ${ }^{61}$.

W związu z tym, że dotychczasowe działania podejmowane przez samorządy w zakresie przeciwdziałania alkoholizmowi nie zawsze były skuteczne, warto rozważyć połączenie działań sformalizowanych i nieformalnych. Zarysowana w niniejszym opracowaniu kwestia uprawnień do opracowania programów profilaktyki, prowadzi do konstatacji, że alkoholizm należy do zjawisk społecznych, względem których skuteczniejsza może okazać się działalność na innych płaszczyznach życia mieszkańców (np. edukacja, zdrowie) niż za pośrednictwem prawa ${ }^{62}$. Nadużywanie alkoholu jest skomplikowanym problemem społecznym, którego rozwiązanie zależy od wielu czynników - medycznych, psychologicznych, organizacyjnych itp. Przepisy u.w.t. przewidują różne działania zmierzające do przeciwdziałania i usuwania następstw nadużywania alkoholu i wskazują na konieczność kompleksowego podejścia do kwestii alkoholizmu ${ }^{63}$, stąd też obowiązek opracowywania programu profilaktyki - którego skuteczność dotychczas była dyskusyjna - uzupełniony i wsparty zostać może innymi działaniami. Wynikające z preambuły do Konstytucji rzetelność i sprawność działania instytucji publicznych wymagają racjonalności w działaniach władz, w tym także związanych z tworzeniem różnego rodzaju aktów normatywnych. Akty te nie zawsze służą dobru wspólnemu, stać się mogą źródłem konfliktów. Państwo, które jest dobrem wspólnym wszystkich obywateli, powinno działać skutecznie i racjonalnie ${ }^{64}$.

${ }^{59}$ K. Wlaźlak, Inflacja prawa administracyjnego $w$ zakresie planowania, w: P. Suwaj (red.), Inflacja prawa administracyjnego, Warszawa 2012, s. 118.

60 Wyrok TK z 22 czerwca 1999 r., K 5/99, OTK-ZU 1999, nr 5, poz. 100.

${ }^{61}$ K. Kłosowska-Lasek, Działania nieformalne administracji w kontekście jej sprawności, w: D. Kijowski, A. Miruć, A. Suławko-Karetko (red.), Jakość prawa administracyjnego, Warszawa 2012 , s. 139.

${ }^{62}$ R. Budzisz, B. Jaworska-Dębska, K. Wlaźlak, op. cit., s. 98.

${ }^{63}$ P. Wilczyński, Dobro człowieka jako zasada administracyjnoprawnych regulacji przeciwdziałania uzależnieniu od alkoholu i jego skutkom, w: Z. Duniewska, M. Stahl, A. Krakała (red.), Zasady w prawie administracyjnym. Teoria, praktyka, orzecznictwo, Warszawa 2018, s. 318.

${ }^{64}$ R. Piotrowski, Ustrojowe konsekwencje inflacji prawa, w: W. Brzozowski, A. Krzywoń (red.), Leges ab omnibus intellegi debent. Księga XV-lecia RCL, Warszawa 2015, s. 387. 
Alkoholizm niesie z soba poważne konsekwencje zdrowotne, społeczne i psychologiczne. Choroba alkoholowa powoduje zaburzenia prawidłowego funkcjonowania rodziny, przemoc, przestępczość i zniszczenie więzi z bliskimi. Ostatnie zmiany ustawodawcze dotyczące sporządzania programów profilaktyki zapoczątkować mogą nowe, być może skuteczniejsze, metody reagowania na nadużywanie alkoholu.

prof. dr hab. Roman Hauser

Uniwersytet im. Adama Mickiewicza w Poznaniu

rhauser@amu.edu.pl

mgr Marta Szustkiewicz

Biuro Orzecznictwa Naczelnego Sqdu Administracyjnego

mszustkiewicz@nsa.gov.pl

\section{THE RATIONALITY AND EFFICIENCY OF PLANNING ON THE EXAMPLE OF A MUNICIPAL PROGRAMME FOR PREVENTING AND SOLVING ALCOHOL-RELATED PROBLEMS}

\section{Sum mary}

In the system of legal sources, apart from typical acts of local law created in accordance with the provisions of the Constitution, there are also acts that do not fall within the constitutional standards of law, although they concern, among other things, important social and economic issues. Such documents (planning acts, programmes, or strategies), although enacted by resolutions, often fail to contain generally binding regulations. Although this does not prevent them from having a binding force, they should nevertheless be made in compliance with the generally recognised rules of lawmaking, including the principles of proportionality, rationality, communicativeness and brevity. The generally applicable provisions often impose on local self-governments an obligation to create acts regulating important social issues, such as for instance programmes preventing and solving alcohol-related problems and determining the way of dealing with alcohol addiction in local conditions. However, these programmes are often developed in violation of the rules of a rational law-making process, and are frequently detached from the local reality, which makes them ineffective. Therefor it may be worth considering another way of responding to the problem of alcoholism, not necessarily by means of resolutions adopted annually. The obligation to develop a prevention and resolution programme addressing alcohol-related problems could be replaced, for example, by certain specific organisational measures, an educational programme, or the implementation of other measures. The law is not always the right way to achieve the goals set, but the above recommendation will requires statutory changes first, anyway. 